\title{
Recent Progress in Development and Manufacturing of SOFC at Topsoe Fuel Cell A/S
} and Risø DTU

Christiansen, Niels; Holm-Larsen, Helge; Primdahl, Søren; Wandel, Marie; Ramousse, Severine; Hagen, Anke

\author{
Published in: \\ E C S Transactions \\ Link to article, DOI: \\ $10.1149 / 1.3569980$ \\ Publication date: \\ 2011
}

Link back to DTU Orbit

Citation (APA):

Christiansen, N., Holm-Larsen, H., Primdahl, S., Wandel, M., Ramousse, S., \& Hagen, A. (2011). Recent Progress in Development and Manufacturing of SOFC at Topsoe Fuel Cell A/S and Risø DTU. E C S Transactions, 35(1), 71-80. https://doi.org/10.1149/1.3569980

\section{General rights}

Copyright and moral rights for the publications made accessible in the public portal are retained by the authors and/or other copyright owners and it is a condition of accessing publications that users recognise and abide by the legal requirements associated with these rights.

- Users may download and print one copy of any publication from the public portal for the purpose of private study or research.

- You may not further distribute the material or use it for any profit-making activity or commercial gain

- You may freely distribute the URL identifying the publication in the public portal 


\title{
Recent Progress in Development and Manufacturing of SOFC at Topsoe Fuel Cell A/S and Risø DTU
}

\author{
N. Christiansen ${ }^{a}$, H. Holm-Larsen ${ }^{a}$, S. Primdahl ${ }^{a}$, M. Wandel ${ }^{b}$, S. Ramousse ${ }^{b}$, A. Hagen ${ }^{b}$ \\ ${ }^{a}$ Topsoe Fuel Cell A/S, Nymøllevej 66, DK-2800 Lyngby, Denmark \\ ${ }^{\mathrm{b}}$ Risø DTU, DK-4000 Roskilde, Denmark
}

The SOFC development at Topsoe Fuel Cell A/S (TOFC) and Risø DTU is based on a R\&D consortium which includes material development and manufacturing of materials, cells and stacks with metallic interconnects focussing on high electrochemical performance, durability and robustness. A significant effort is directed towards improvement of current generations as well as development of the next generation SOFC technology. The innovative concept of the next generation, aiming at improved reliability and robustness, is based on metal-supported cells and nano-structured electrodes with perspectives of several potential advantages over conventional Ni-YSZ anode supported cells. Recently, record-breaking results have been obtained on cell level as well as on stack level. The collaboration has the objective to effectively transfer scientific results to industrial technology upscaling and application. TOFC is engaged in development and demonstration of stack assemblies, multi-stack modules and PowerCore units that integrate stack modules with hot fuel processing units.

\section{Introduction}

The consortium of Topsoe fuel Cell (TOFC) and Risø DTU has undertaken the task of developing and capturing knowledge to initiate up-front R\&D and innovation projects and to transfer the knowledge to applied technology. Many years of collaboration between Risø DTU and TOFC on SOFC development has ensured an efficient establishment and transfer of technology and up-front knowledge. TOFC provides the SOFC technology platform: Cells, stacks, and integrated stack module for different applications, and collaborates with integrator partners to develop, test and demonstrate SOFC applications. More fundamental R\&D including advanced characterisation is carried out at Risø DTU.

The consortium has been actively developing SOFC since 1989 resulting in several generations of continuously improved thin planar cells based on the anode-supported concept. The development includes materials, stack and system components, cell stack and system designs, testing, fabrication techniques, improved understanding and mitigation of performance degradation mechanisms. Furthermore, the development includes application of modelling, simulation and verification of cell stack and system designs (1). The overall approach of the consortium is based on an effective follow-up on all critical technical issues in the whole value innovation chain. During 2009-2010, the 
cell manufacturing for stack production has been transferred from the production development facility at Risø to a new TOFC production facility, which has liberated the pilot cell manufacturing facility at Risø to explore new material alternatives, recipes and processes, boosting the mid to long term development.

TOFC is currently improving stack power density and durability by introducing electrodes with new compositions and new component processing technologies. Today standard TOFC stacks with a footprint of $18 \times 18 \mathrm{~cm}^{2}$ operate in the $3 \mathrm{~kW}$ power range. Efforts include a focus on durability and robustness under real operation conditions such as fuels with sulphur impurities and air with increased humidity. The current improved $2.5 \mathrm{G}$ cell concept (see below) has been tested in the TOFC stacks with $12 \times 12 \mathrm{~cm}^{2}$ for more than 10,000 hours with degradation rates of about $7 \mathrm{mV} / 1000 \mathrm{~h}$, at $0.22 \mathrm{~A} / \mathrm{cm}^{2}, 750$ ${ }^{\circ} \mathrm{C}$, corresponding to $30 \mathrm{~m} \Omega \mathrm{cm}^{2} / 1000 \mathrm{~h}$. Evaluation of Sc-doped zirconia in anodes as well as in electrolytes has resulted in improved performance. Development activities are currently directed towards further understanding and solving problems with degradation. New materials for electrodes and electrolytes, making it possible to operate cells with low voltage degradation at higher current densities and with industrial gasses, has a high priority within the consortium of TOFC and Risø DTU.

Aiming at reliability, robustness and low material cost, TOFC/Risø has increased the efforts on development of next generation cells with metallic support including novel nano-structured electrodes and Sc-doped zirconia electrolyte materials for operation in the temperature range $600-700{ }^{\circ} \mathrm{C}$. A novel stack design is currently under development where the concept of introducing more reliable parts in the stack design for increased robustness is pursued.

The vision of being a leading edge SOFC developer is realized through effective $R \& D$ and innovation strategies. Expansion and strengthening of the world-wide collaboration network contribute to a continuous development and improvement. TOFC is coordinating the EU project METSOFC concerning development of novel metal supported SOFC in addition to a number of national SOFC development projects, which brings the technology beyond state of the art (see below). Furthermore TOFC and Risø participate in a large number of different European SOFC development projects.

The first of a new lightweight high power density stack, based on a radical modified planar stack design has been developed and tested in collaboration with United Technologies Research Center. The TOFC delivery is a thermal insulated $2.3 \mathrm{~kW}$ stack with an integrated stack compression system optimized with respect to weight and volume for critical mobile applications (2). Currently, the new stack design is being modified for integration into diesel fuelled systems for APU applications.

TOFC's new cell and stack production facility is constructed to meet the growing demand in the test and demonstration phase and to improve the technology readiness level. The facility comprises all unit operations, from ceramic powder processing to cell manufacturing and assembly of final stacks. Furthermore, the facility includes a large number of advanced test units for test of stacks, PowerCores and fuel processors.

\section{Cell Development and Manufacturing}


The cell production facility at Risø jointly operated by Risø DTU and TOFC has served the purpose of development of new improved cell manufacturing methods as well as manufacturing of new cell types with new and improved cell materials and components. The process development is based on in-house industrial processes, such as tape casting, spray painting, and screen printing. Furthermore, the work includes verification of alternative cost effective processes, such as multilayer tape casting, aqueous tape casting, lamination of cell component layers and environmentally benign processing.

The development of cells is based on an incremental approach as well as radical new innovation. $2 \mathrm{G}$ cell technology represents the classical anode-supported cells with LSM cathodes, whereas the $2.5 \mathrm{G}$ generation anode-supported cells have LSCF cathodes and CGO diffusion barrier layer for operation with high power density at lower temperatures. In the continuing incremental development, new cathode materials such as LSC cathodes as well as new manufacturing processes are investigated. Progress in processing of cells has resulted in improved performance characteristics over a larger electrode polarization compared to standard $2 \mathrm{G}$ cells. A $34 \%$ lower ASR of these cell compared to standard $2 \mathrm{G}$ cells has been obtained. Detailed impedance analysis show that the improved performance of these cells is mainly due to a significant decrease of the Ni-YSZ charge transfer resistance at the triple phase boundary, suggesting that the new processing method has resulted in an improved anode. Furthermore, the process development is aiming at minimizing the number of processing steps in the manufacturing. The $3 \mathrm{G}$ cell concept represent a radical innovative technology based on a robust ferittic stainless steel powder-metallurgical metal support with an anode transition layer, a thin electrolyte layer and nano-structured electrodes (see below).

\section{Ceramic (anode-supported) cells}

The performance of the cathode and anode has been improved concurrently by further development of microstructures and materials. Specifically, Sc doped YSZ was used in the anode/electrolyte. These cells usually show a better initial performance than those without Sc doping. In addition, the sulphur tolerance has bee enhanced (3). On the cathode side, LSC as single phase or composite has been studied and implemented in experimental series, in particular for lowering the operating temperature from about 800 ${ }^{\circ} \mathrm{C}$ to $700{ }^{\circ} \mathrm{C}$.

Both development lines have resulted in cells which show superior durability at lower operating temperatures compared to the conventional Ni/YSZ/LSM based SOFCs, especially at high current densities and at real air compositions with environmental humidity (4). Figure 1 shows a durability test on a single cell with single phase LSC cathode. From impedance data it can be concluded, that the anode contributes to the major part of the degradation over the first few hundred hours (see Figure 2, red symbols). No cathode degradation can be observed (see Figure 2, green symbols). 


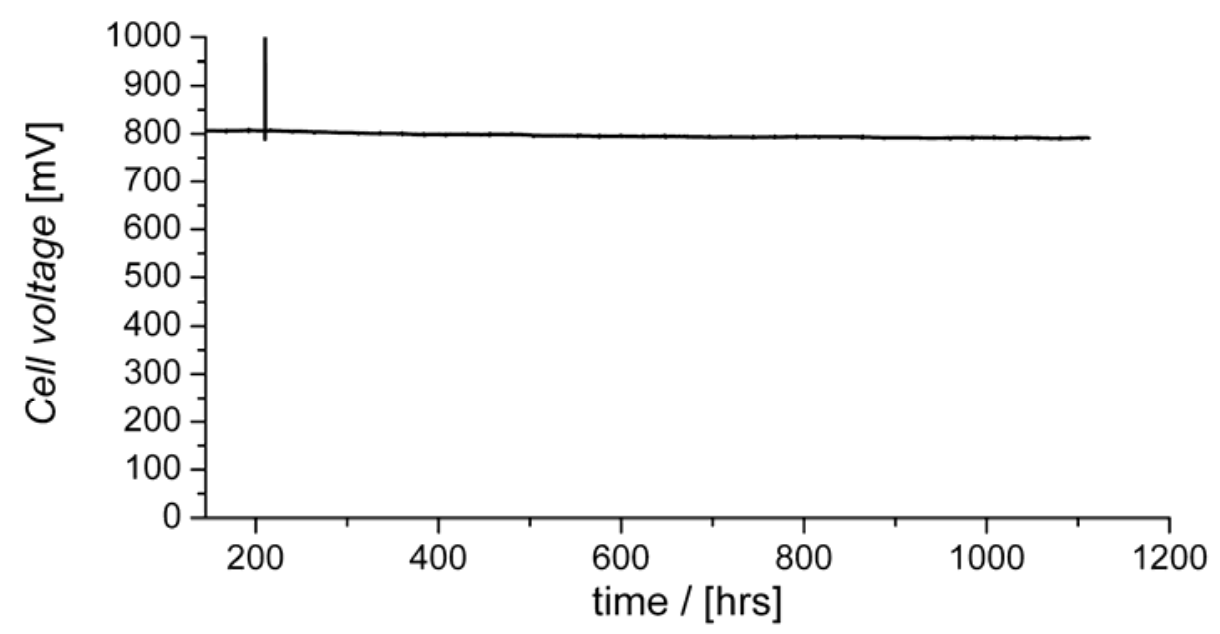

Figure 1. Single cell durability test at $700{ }^{\circ} \mathrm{C}, 20 \%$ OU (synthetic air) and $60 \% \mathrm{FU}$ (hydrogen), $0.5 \mathrm{~A} / \mathrm{cm}^{2}$.

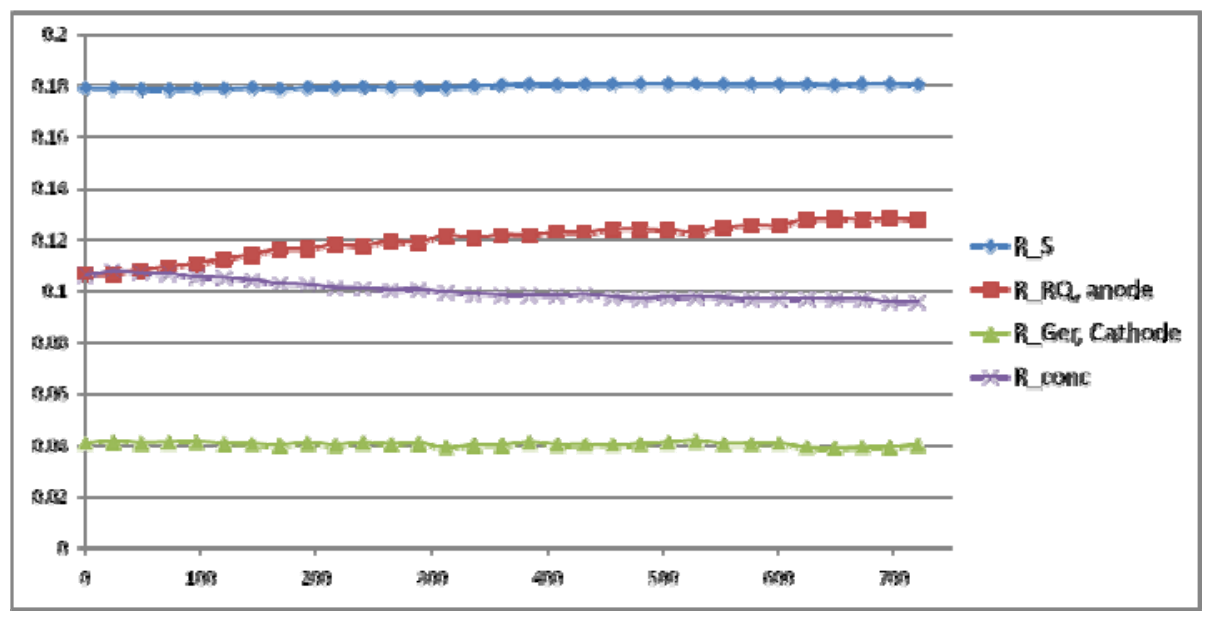

Figure 2. Cell component impedance contributions recorded from impedance spectra under current load.

Figure 3 shows a cell test combining the cell development lines mentioned above including new materials and improved processing. An overall voltage degradation of only $4.2 \mathrm{mV} / 1000$ hour corresponding to $0.5 \% / 1000$ hour or $8.4 \mathrm{~m} \Omega \cdot \mathrm{cm}^{2} / 1000$ hour at 0.5 $\mathrm{A} / \mathrm{cm}^{2}, 700{ }^{\circ} \mathrm{C}$ and $60 \%$ fuel utilization was obtained with this cell. From I/V curves at $750{ }^{\circ} \mathrm{C}, 20 \% \mathrm{H}_{2} \mathrm{O}$ in $\mathrm{H}_{2}$ with $60 \%$ fuel utilization, it was found that the fuel utilization corrected cell ASR was $0.2 \Omega \mathrm{cm}^{2}$. From impedance spectra, it was found that the ohmic resistance decreased whereas the polarization resistance increased during the 1000 hour test (See Figure 3 bottom). As the cathode contribution remained constant for the entire period, the overall degradation could be attributed to the anode. 

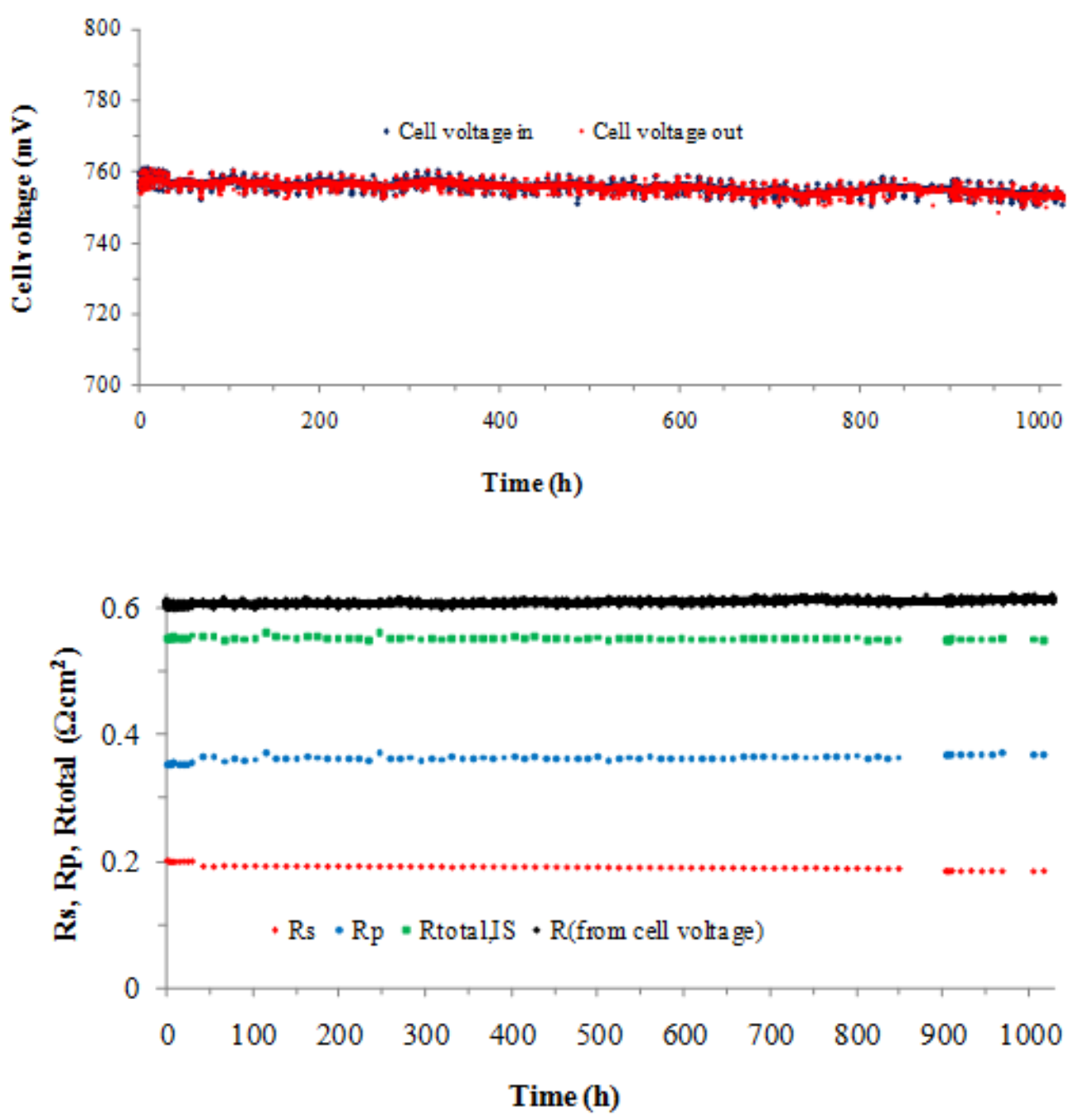

Figure 3. Durability test at $0.5 \mathrm{~A} / \mathrm{cm}^{2}, 700{ }^{\circ} \mathrm{C}, 4 \% \mathrm{H}_{2} \mathrm{O}$ in $\mathrm{H} 2\left(60 \% \mathrm{H}_{2}\right.$ utilization) and synthetic air to the cathode, impedance spectra recorded under current load.

\section{Metal-supported cells (3G)}

The metal-supported cell technology is aiming at increased robustness and reliability. The innovative concept ensures that the number of different steps in the manufacturing is minimized at the same time as industrial relevant methods are chosen (5). The multilayer processed half cell is co-sintered in $\mathrm{H}_{2}$ atmosphere, followed by infiltration of the active electrode components. Several advantages over conventional anode-supported cells are expected such as: increased resistance against mechanical and thermal stresses, ductility during handling and processing, robust seals based on welding and brazing and reduction in material cost.

Reduced operation temperatures in the range of $650-700{ }^{\circ} \mathrm{C}$ demand new highly active and stable electrode materials while internal fuel reforming and heat balances becomes more easily controlled. Improvements of the microstructure of electrodes and electrolyte as well as the material selection in question can explain the low degradation rate described further below and in references. The best cells today have ASR between $0.27-0.33 \Omega \mathrm{cm}^{2}$ at $650{ }^{\circ} \mathrm{C}$, corresponding to a maximum power density of $1.14 \mathrm{~W} / \mathrm{cm}^{2}$. 
Cells with different anodes (6) and different types of CGO barrier layers between the cathode and the electrolyte have been investigated (7). For the LSC cathode chosen, it appeared that the ASR of the cells correlated to the quality of the barrier layer. The lowest ASR was obtained with CGO barrier layers applied by PVD. Figure 4 shows that a steady state degradation rate of about $1 \%$ per 1000 hours could be obtained during a 3000 hour durability test on a $5 \times 5 \mathrm{~cm}^{2}$ cell $\left(16 \mathrm{~cm}^{2}\right.$ active area) at $650{ }^{\circ} \mathrm{C}$. Despite the very promising performance results obtained with the novel metal-supported cell design, the long-term stability still needs to be improved in order to fulfill longevity requirements in stationary applications.

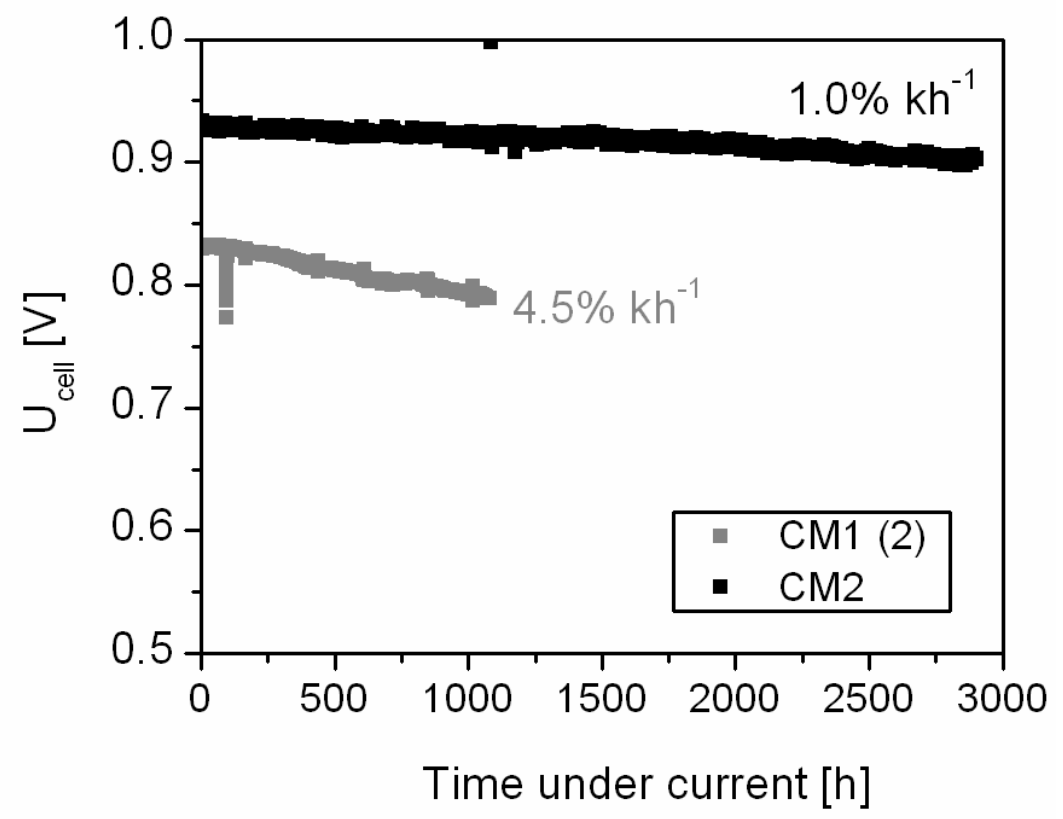

Figure 4. Galvanostatic durability curves of metal-supported cells with $16 \mathrm{~cm}^{2}$ active area, recorded at $650{ }^{\circ} \mathrm{C}$, with a current density of $0.25 \mathrm{Acm}^{-2}$, and $\mathrm{H}_{2}-4 \% \mathrm{H}_{2} \mathrm{O}$ as fuel and air as oxidant. Upper and lower curves represent two different anode structures (7).

\section{Development of robust stacks}

As the SOFC technology and markets are transitioning from development phase to test and demonstration phase, the focus on reliability and robustness is steadily increasing. Operation of stacks under real systems conditions reveals how the components suffer from stresses induced by temperature gradients, cycling conditions and external mechanical loads exerted by the stack and system design in question. In order to evaluate the robustness of the current TOFC stack design based on ceramic anode-supported cells and to obtain information about possible failure mechanisms, a test program based on harsh or accelerated load conditions has been initiated (8). Figure 5 shows an example comparing the total stack ASR at beginning of life with the ASR values after different harsh robustness tests of a $12 \times 12 \mathrm{~cm}^{2}$ footprint stack with anode-supported cells. The test protocol has been selected to stress all critical component interfaces thereby testing the 
robustness against e.g. loss of contact, damage of interfaces, creep of steel components and cell cracking. The test includes the following operation boundary conditions:

1) Simulation of a system failure, which induces rapid and large changes in temperature profile of the stack stressing the components and component interfaces due to TEC mismatches: A number of severe load cycles are performed by immediate current load steps between 0.1 and $0.3 \mathrm{~A} / \mathrm{cm}^{2}$ without any changes in air or fuel flow with a 30 min stabilisation at each load level.

2) Simulation of a system failure (i.e. blower), which creates altered thermomechanical stresses at temperatures higher than what the components are initially designed for: Stack superheating is performed by altering the fuel type from simulated pre-reformed natural gas to $\mathrm{H}_{2}$ and increasing the current load to $0.5 \mathrm{~A} / \mathrm{cm}^{2}$ creating a maximum stack temperature of about $150^{\circ} \mathrm{C}$ above design point.

3) Simulation of loss of compression load or handling of stack without compression in cold state: The stack has been cooled down, and the compression is subsequently removed. Reapplying compression and starting up again, the stack displays insignificant ASR increase.

Figure 5 shows that the ASR increase is below 5\% after execution of all 3 test types indicating good robustness properties of the stack design in question.

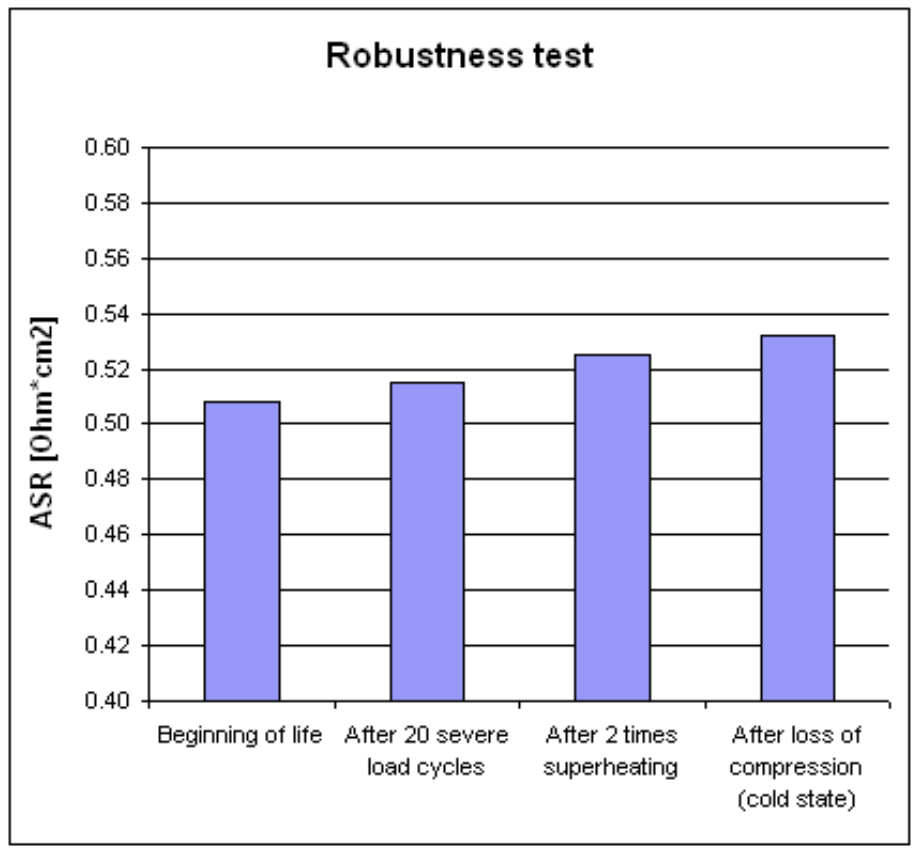

Figure 5. ASR measured after different robustness tests $@ 750^{\circ} \mathrm{C}, 0.3 \mathrm{~A} / \mathrm{cm}^{2}$.

TOFC has for several years concurrently studied different available commercial and experimental steel alloys for the metallic interconnects regarding oxidation rate, break away corrosion, cyclic oxidation and electrical conductivity (9). Today a number of different ferittic stainless steel alloys with compositions tailored for SOFC application are 
commercially available as strip steel. Figure 6 shows the results of an in-house oxidation test of three different commercial available ferittic stainless SOFC strip steels revealing quite dramatic different corrosion properties.
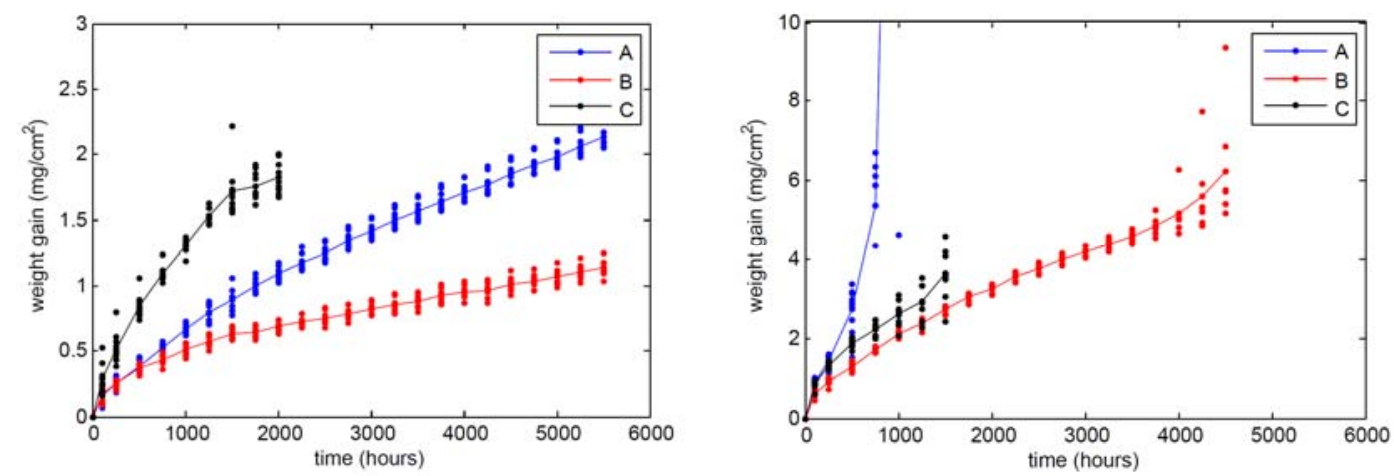

Figure 6. Weight gain during oxidation test of three different commercial SOFC ferittic stainless strip steels. Left at $800{ }^{\circ} \mathrm{C}$, right at $900{ }^{\circ} \mathrm{C}$.

\section{System Development}

TOFC is engaged in demonstration activities together with technology partners within the field of several promising segments. Prototype PowerCore units, integrating the stack module with hot fuel processing units such as reformer, heat exchangers, catalytic burner, thermal management, thermal insulation and instrumentation, have been designed for micro CHP application in the $1.4 \mathrm{~kW}$ range (se Figure 7). The PowerCore DC efficiency with anode recycle is more than $60 \% \mathrm{LHV}$ at $1.3 \mathrm{~kW}$. It has been tested successfully as a part of the national Danish micro CHP program. The project target is to deliver 15 PowerCore units to the Danish system partner Dantherm Power for system field test in 2011. A scaleable modular multi-stack concept is under development for larger SOFC systems.

A significant design flexibility of the TOFC multilayer SOFC stack design, as well as flexibility in selection of cell materials, offers the possibility of modifications in order to fulfil specific application requirements. The light weight stack optimized for short life time is currently modified for APU applications with more than 5000 hours lifetime. Stack operation with CPO reformed JP8 and diesel has recently been demonstrated successfully together with suppliers of CPO reformers. 

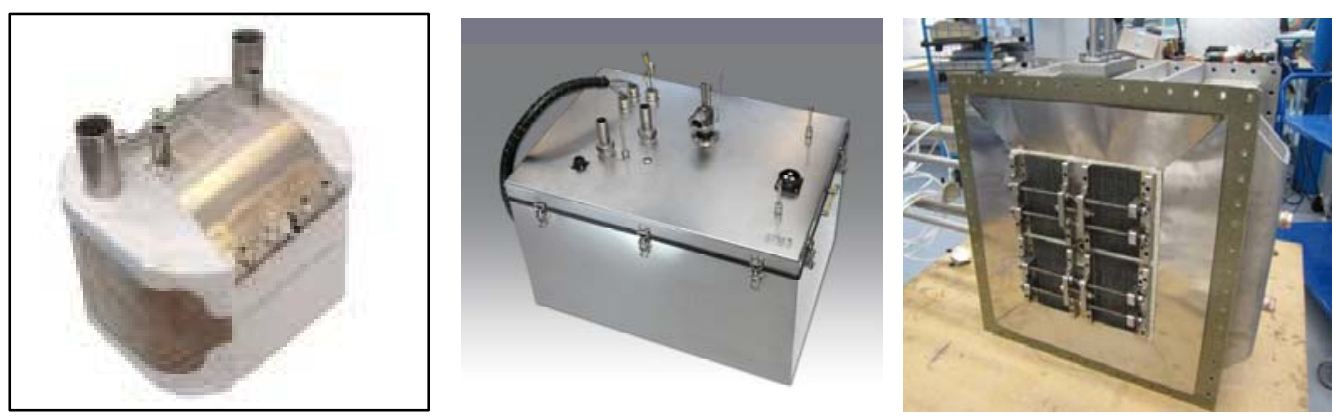

Figure 7. TOFC light weight stack, PowerCore and multi-stack module.

Following operation and test of $20 \mathrm{~kW}$ natural gas fuelled alpha and beta prototypes at Wärtsilä containing 24 TOFC stacks, a significant number of stacks have been supplied for further test and prototype demonstration. The $20 \mathrm{~kW}$ methanol-based unit is part of Wärtsilä's comprehensive SOFC demonstration programme. The unit has been operated successfully as a ship APU for more than 1250 hours under harsh conditions on board the cargo vessel Undine sailing between Europe, North America and Southeast Asia. Haldor Topsø A/S has supplied the methanol methanator catalyst for the fuel processing. Another $20 \mathrm{~kW}$ SOFC system (see Figure 8) for biogas/landfill-gas, built and operated by Wärtsilä containing 24 TOFC stacks, has been operated on purified landfill gas for more than 2000 hours (10).

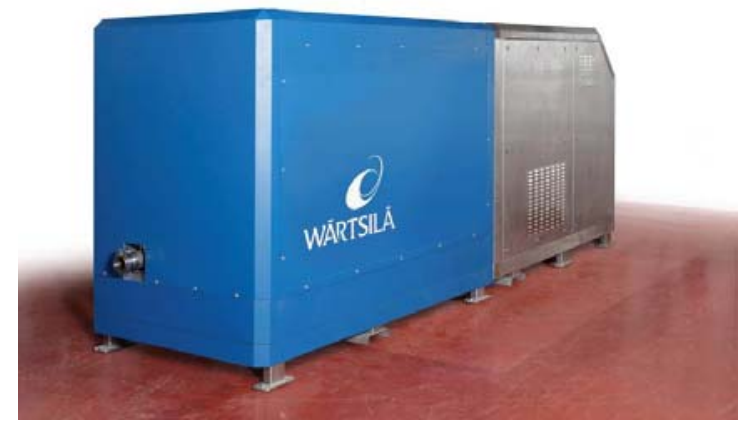

Figure 8. Wärtsilä FC 20 unit (10).

\section{Acknowledgments}

The Authors acknowledge the EU project FP7-211940 METSOFC, EU-LIFE, The Danish National Advanced Technology Foundation and DK-Energinet / EUDP.

\section{References}

1. N. Christiansen, S. Christensen, H. Holm-Larsen, P. H. Larsen, M. Mogensen, P. V. Hendriksen, ans S. Linderoth, The Electrochemical Society Proceedings, PV 2003-07, p. 105-112, Pennington (2003).

2. N. Erikstrup, M. D. Jensen, M. R. Nielsen, T. N. Clausen and P. Larsen, ECS Trans., 25(2), 207-212 (2009). 
3. A. Hagen and J. F. B. Rasmussen, European SOFC Forum Proceedings, Lucerne (2010).

4. A. Hagen, M. Chen, K. Neufeld and Y. Liu, ECS Trans., 25(2), 439-446 (2009).

5. P. Blennow, J. Hjelm, T. Klemmensø, S. Ramousse, S. Kromp, A. Leonide, A. Weber, European SOFC Forum Proceedings, Lucerne (2010).

6. P. Blennow, T. Klemmensø, Å. H. Person, K. Brodersen, A. K. Srivastava, B.R. Sudireddy, S. Ramousse, M. Mogensen, ECS Trans., in this volume, (2011).

7. T. Klemmensø, J. Nielsen, P. Blennow, Å. H. Person, T. Stegk, P. Hjalmarsson, B. H. Christensen, S. Sønderby, J. Hjelm, and S. Ramousse. ECS Trans., in this volume, (2011).

8. N. Christiansen, J. B. Hansen, H. H. Larsen, M. J. Jørgensen, M. Wandel, P. V. Hendriksen, A. Hagen and S. Ramousse, ECS Trans., 25(2), 133-142 (2009).

9. P. Huczkowski, S. Ertl, J. P. Abellan, N. Christiansen, T. Höfler, V. Shemet, L. Singheiser, and W. J. Quadrakkers, Microscopy of Oxidation, 79-88, Science Reviews (2005).

10. M. Noponen, T. Hottinen, European SOFC Forum Proceedings, Lucerne (2010). 